\title{
TOLEHO
}

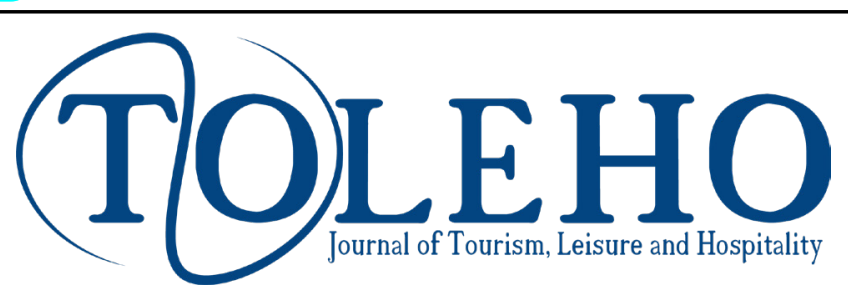

\section{THE PROJECTED IMAGE OF TURKEY IN TRAVEL BLOGS}

\author{
Adil Bical ${ }^{\mathrm{a},},{ }^{*}$, N. Canan Öztürk ${ }^{\mathrm{b}}$ \\ ${ }^{\mathrm{a}}$ Department of Advertising, Gaziantep University, Gaziantep, Turkey \\ ORCID: 0000-0001-6139-5497 / e-mail: adilbical@gantep.edu.tr, \\ ${ }^{\mathrm{b}}$ Department of Public Relations and Advertising, Anadolu University, Eskisehir, Turkey \\ ORCID:0000-0002-2677-6902 / e-mail:mozturk@anadolu.edu.tr
}

\begin{tabular}{|c|c|}
\hline KEYWORDS & ABSTRACT \\
\hline Turkey & Travel and destination information is mostly provided by textual and storytelling communication practices. \\
\hline Destination image & With the spread of mobile phones, digital tools and Web 2.0, photographs have become an important medium \\
\hline Photo & for reflecting destinations. This study analyses how Turkey is visualized and reflected as a destination through \\
\hline Thoto & photos by the top 100 most-visited travel bloggers. As a result of the research, predictable findings (e.g. the \\
\hline Travel blogs & most visited city: Istanbul or the most interesting historical monuments: Sultan Ahmet, Hagia Sophia) were \\
\hline & obtained, and unexpected results were also gathered by the researchers. Among these, street cats ( 31$)$ attract \\
\hline & the same level of curiosity as the Topkapi Palace (34), and bloggers shared Cappadocia's (21\%) photos more \\
\hline & $\begin{array}{l}\text { than all coastal regions involved in intense of tourism }(17 \%) \text {. These results imply clues on which destinations } \\
\text { or attractions of Turkey should be emphasized and provide some information about Turkey's image as a } \\
\text { destination. }\end{array}$ \\
\hline
\end{tabular}

\section{Introduction}

Professionals and researchers have been interested in creating, supporting or changing the image of tourism in tourism marketing for many years. In these studies, the main objectives are to bring the images that exist and the images that are targeted together and equalize them if possible (MacKay \& Fesenmaier, 1997). In this context, photographs have been used in many areas such as postcards, advertisements, tourism brochures and magazines to promote tourism activities and support the images of destinations (Baloglu \& Mangaloglu, 2001; Baloglu \& McCleary, 2016; Garrod, 2008). Travel photos provide evidence for researchers in several aspects. On the one hand, they serve as additional data to understand the views of the tourist experience and the associated travel environment (Albers and James 1988), while, on the other hand, they provide clues about the image of the destination. Therefore, researchers have studied, especially before the spread of the internet, postcards and brochures to find how destination images are presented visually (Gaman \& Răcășan, 2015; Markwick, 2001; Yüksel \& Akgül, 2007).

On the other hand, photographs were used to understand how travellers perceive a region or tourist activity (Albers \& James, 1988; Markwell, 1997). In recent years, with the widespread use of the internet and taking into account that travellers are headed to travel sites, blogs or social media, studies have started to focus on the use of tourism- related visual materials in these areas (Choi, Lehto, \& Morrison, 2007; Ren, Vu, Li, \& Law, 2020; Stepchenkova \& Mills, 2010; Zhang, Chen, \& Li, 2019; Zhang, Xu, Leung, \& Cai, 2015). The focus of these studies is, based on the content, revealing the basic image components of the relevant destinations.

Both governmental institutions and agencies conduct communication campaigns through advertising, brochures and other marketing communication tools to create a positive destination image. Yet, as current research shows, the information that is out of control and wordof-mouth (WOM) are more effective in shaping the image of a destination (Connell, 2005; Currie, Wesley, \& Sutherland, 2008). With the development of Web 2.0, blogs have had a significant place in noncontrolled communication activities. Travel blogs, along with these developments, are used by many tourists and travel preferences, albeit on different levels (Akehurst, 2008; Cox, Burgess, Sellitto, \& Buultjens, 2009; Ma, Xiang, Du, \& Fan, 2018).

People writing on travel blogs may be considered both amateur and professional travellers. They are usually travelling for a hobby and entertainment purposes without being connected to an institution.

${ }^{\star}$ Corresponding Author.

Received 10.11.2020; Received in revised form 06.01.2021; Accepted 14.01.2021 This article is licensed under a Creative Commons Attribution 4.0 International License. e-ISSN: 2687 - 3737 / ㄷ 2021 The Authors. Published by Anadolu University. http://dx.doi.org/10.48119/toleho.823838 
However, unlike ordinary tourists, they often do this and travel in a particular field such as nature, food and beverage or historical sites, and this expresses their professional aspect. They also act as an "opinion leader" owing to their followers (Song, Chi, Hino, \& Tseng, 2007). These features transform them into a specialist travel guide. For this reason, when many tourists plan their vacations, they benefit from the information provided by these blogs and make travel decisions according to this information (Ma et al., 2018; Phau, Shanka, \& Dhayan, 2010; Zehrer, Crotts, \& Magnini, 2011). In this sense, the main purpose of this study is to understand how travel bloggers perceived Turkey as a destination through the photos they share.

\section{Literature Review}

\subsection{Country, Destination Image and Turkey}

The image represents the sum of beliefs, attitudes and impressions that a person or group has for an object. The object may be a company, product, brand, place or person. The effects may be true or false, real or imaginary, but images guide and shape individuals' attitudes and behaviours (Barich \& Kotler, 1991, p. 95). The image of a country expresses all beliefs and associations related to a country (Mossberg \& Kleppe, 2005). Similarly, the image of a destination is defined as the sum of the accumulated impressions, beliefs, ideas, expectations and feelings about a place (Kim \& Richardson, 2003, p. 218).

Much of the current literature on place or destination images has directions. The first is the product-country image (Country Origin Image, CoI), which has been researched in the field of international marketing for many years and focused on the relationship of country origin products to the image of a country. The other is the tourism destination image (Tourism Destination Image -TDI), which is mostly interested in the tourism literature. Although the evolution of these research areas is usually facilitated separately, both areas focused on how complex images related to a place are ensured and how these images affect individuals (Nadeau, Heslop, O'Reilly, \& Luk, 2008, p. 85).

According to Han (1989), the country image has a halo effect on products. Consumers consider the country image as a reference point to make inferences about an unknown product. Many studies about product and country image support this claim (Baldauf, Cravens, Diamantopoulos, \& ZeugnerRoth, 2009; Hsieh, Pan, \& Setiono, 2004; Li, Lu Wang, Jiang, R. Barnes, \& Zhang, 2014; Pharr, 2015). In other words, the country image acts as an umbrella on the related images of a country and affects these images (e.g. effect of Germany's country image on its design of automobile and machinery products). Some authors claimed that destinations are also a part of a country and, therefore, marketable as a product. Therefore, they stated that the image of a country also serves as an umbrella on destinations (Zhang et al., 2015). Yet, some studies are claiming that the destination image has very different dimensions in comparison to products. Accordingly, destination image, similar to the country image, acts as an umbrella structure over products and services. Unlike the country image, it is considered to be both generic and special product (Echtner \& Ritchie, 1993; Mossberg \& Kleppe, 2005). This is because destinations can be marketed like a special place, region, etc., and they also affect the image of the products and services related to those places.

On the other hand, despite the similarity in the identification of country and destination images in the literature, recent research suggests that these two images should be considered separately for developing countries (Lee \& Lockshin, 2012). Some authors argue that the two concepts are independent of each other, and the country image does not have a full umbrella of "halo" effect on the destination. In some studies, it is revealed that the tourism destination image of some countries differs from their general country image (Nadeau et al. 2008). For example, studies on Nepal (Nadeau et al., 2008), Russia (Stepchenkova \& Morrison, 2006), Turkey (Martínez \& Alvarez, 2010) and Israel (Campo \& Alvarez, 2014) found that even though some countries are perceived as undesirable countries because of their economic or political issues, tourists perceived them as attractive tourism destinations.

\subsection{The Relationship between Blog, Photo and Destination Image}

Although the negative image of a country harms the purchase of a country's products or intention to visit the country, studies revealed that the image of the destination is dynamic. As individuals visit the country or differentiate the information received from external sources, their country's image and intentions may change (Campo \& Alvarez, 2014). On the other hand, if consumers do not have enough information when they want to buy a service or product, they try to eliminate this lack of external resources. In the literature, information sources for external information research are discussed in three categories:

- word-of-mouth (WOM),

- independent resources (consumer reports) and

- market-oriented resources (advertising).

Among these, the effect of WOM was found to be more effective in comparison to other sources in decision making (Cosenza, Solomon, \& Kwon, 2015). Bloggers who create content about a destination and share them with their followers naturally act as an opinion leader and influence their environment (Joyner, 2008; Song et al., 2007). In many studies, it was determined that bloggers influenced their followers in purchasing decisions (Cosenza et al., 2015; Phau et al., 2010; Zehrer et al., 2011). In addition to this, bloggers publish content on their pages, and they are referring to the pages where they 
share this content from their social media accounts. In this context, it is possible to say that bloggers, like a newspaper or a communication medium, carry out an uncontrolled communication activity on the promotion of tourism destinations via social media.

Although information about travel and destination is mostly through textual and narrative communication practices (e.g., blogs and written reviews), sharing of experience is mainly achieved through online audio-visual communication tools (Munar \& Jacobsen, 2014). According to MacKay and Fesenmaier (1997), visuals allow individuals to compare specific experiences in different places and associated tourism potentials. Photographs, which are a visual reflection of the experiences of tourists and their perspective on destinations, play an important role in shaping the image of a destination. Considering the WOM effect, it is thought that bloggers' experiences about a destination and tourism services into visual information and share, make potential tourists assess a place or region image.

On the other hand, regarding the discussion of destination and country image, it is stated that some authors tend to consider and present the destination as a product. The product image created here can have meanings beyond the actual features of the existing product. Similarly, in the context of tourism, product structure has more meaning than the experience of the destination itself (Nadeau et al., 2008). The products presented in destination marketing do not have to be directly related to the destination (such as "Gone with the Wind" and Casablanca / Morocco relationship). The products related to the destination are an image or imagery beyond a place or region. This image may be real or produced. For example, although Romania does not come across as a result of planned tourism activity, it is an example of linking the Transylvanian region of Romania with vampires and supernatural stories in popular culture (Light, 2007).

Thus, from a CoI perspective, it is possible to claim that, as a country is associated with a product destination are offered with some of the products (place, region, experience, entertainment, etc.) that are prominent while being marketed as a product. From this perspective, the visuals shared by tourists reveal the products with which the destination is more prominent and how the destination is perceived. Considering the scope of this study, the determination of the shares of tourists who spend time in these areas may provide the opportunity to determine which products or services are associated with these regions. In previous studies, research has often focused on how destinations are presented in various materials (brochures, films, magazines, etc.). Nevertheless, there is a lack of assessments of how tourists perceive a destination.

In this context, it should be kept in mind that photographs from these sources will have a significant impact on shaping the image of a destination. However, in a limited number of studies, the relationship between photography and destination image was handled in terms of tourism marketing. Some studies found significant results for understanding destination image (Choi et al., 2007; Stepchenkova \& Zhan, 2013; Tudor, 2012). They revealed the tourism potentials of the countries examined in these studies.

In the light of such information, the main objective of this study is to determine Turkey's tourism image in the eyes of bloggers. The differences between the images of tourism agencies and bloggers may be determined from the images (photos, videos, maps) shared by the bloggers. Similarly, it is aimed to determine which tourism regions come to the forefront from the sharing of bloggers and areas that are not popular but in which bloggers are interested. The data to be obtained are expected to shed light on with which aspects of tourism in Turkey should be improved and marketed for marketing practitioners.

\section{Method}

This study aims to determine how Turkey is presented in travel blogs. To achieve this aim, photographs taken by bloggers were analysed by the quantitative content analysis method. The main purpose of content analysis is to bring together similar data and interpret them in the context of specific concepts and themes (Şimşek \& Ylldırım, 2016, p. 242). For this study, content analysis was considered to be an appropriate method. To achieve these objectives, the following questions were addressed:

- Which themes have come to the fore the most in the photographs related to Turkey in travel blogs?

- Which regions of Turkey are included more in the photos?

- With which issues are the touristic regions and cities of Turkey mentioned in the photos?

- Do the travel interests of bloggers towards Turkey vary based on their nationalities?

\subsection{Bloggers Selection}

To decide which travel blogs to be examined within the sample, we reviewed the tourism literature and analysed former studies. But there have not been sufficient studies in the literature. Instead of the academic literature, we considered and used the www.rise.global/travel1k list. It is a ranking website around the world tracking many tourism blogs based on the level of interaction with their followers on social media. The rankings of travel bloggers on this site change every 15 days. This study was based on the list obtained on July 28, 2017 (https://www.rise. global/travel1k/r/2519929?public=n). The first 120 blog sites were chosen as the sample. The list was created regardless of the nationality of bloggers, but within the first 120 , there was no blogger from Turkey. 


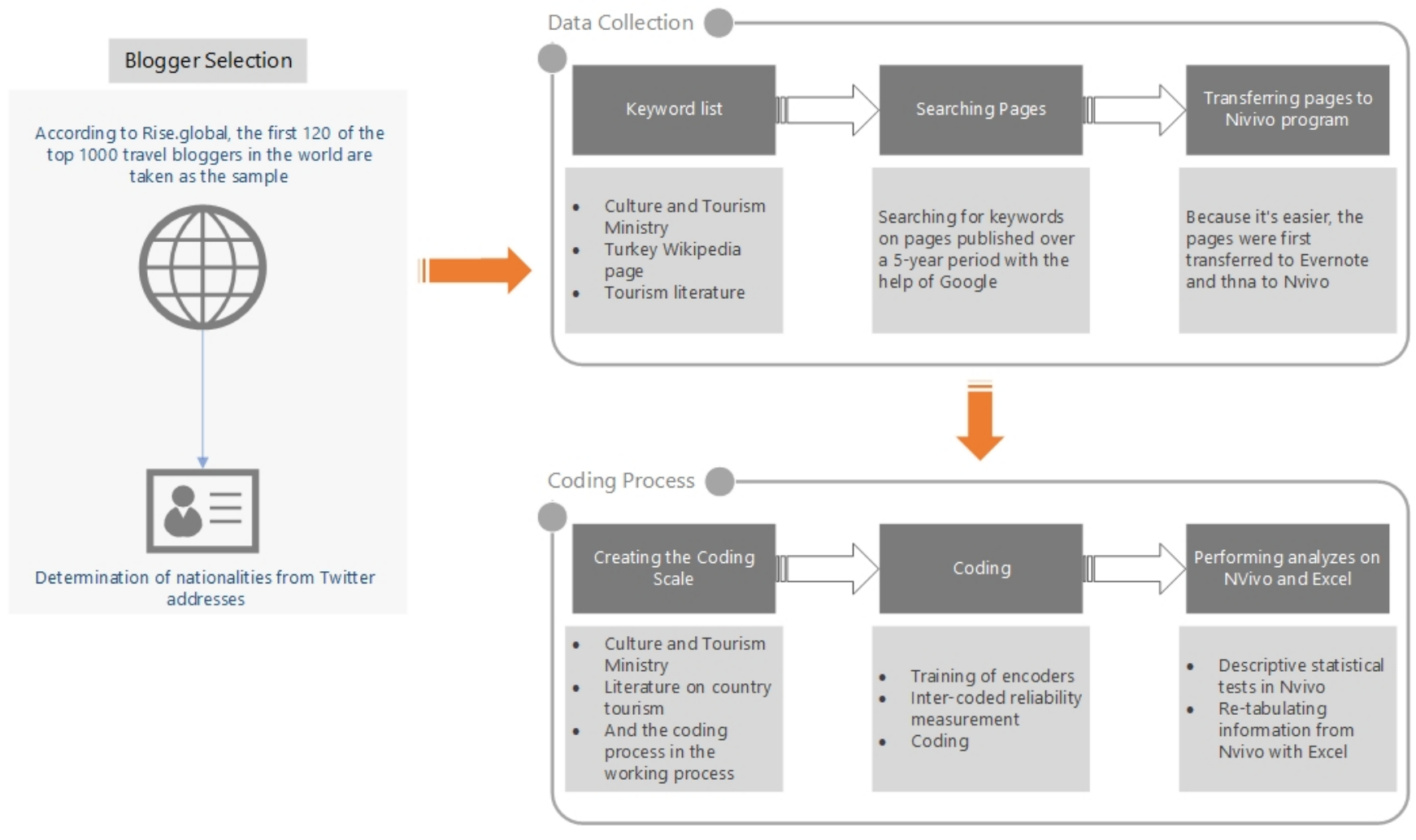

Figure 1. Content analysis process

\subsection{Data Collection}

Şimşek and Yıldırım (2016) recommended that, if a content analysis study is not started from a theory, then, firstly a coding scale should be created, and after that, themes should be found based on the relationship statuses of these codes. When coding is completed, it is necessary to analyse the data and interpret them accordingly. Figure 1 shows the content analysis process based on this information. There is a detailed description of this process below.

Creating Keywords: To access bloggers' shared information about Turkey, we defined which words could define Turkey. According to this, keywords concerning Turkey were created. Keywords were created as a result of searches on Wikipedia.org, the website of the Turkish Ministry of Culture and Tourism and thanks to a review of the relevant literature. On the other hand, the first 5 websites were examined, and according to the data obtained, the keywords were formed as follows:

"Cappadocia Gallipoli Turkey Turk Turkish Istanbul Hagia Sophia Topkapi Dolmabahce Galata Nemrut Antalya Bodrum Marmaris Olympos Ephesus Troy Pamukkale Trabzon Konya Antioch Mardin Diyarbakir Ankara Atatürk Edirne Trabzon"

Identification of blog sites' pages related to Turkey and transferring contents to Nvivo: The Google search engine was used for the blog sites to identify the data to be examined within the scope of the study. In these blogs via the Google Search Engine, the keywords were searched, and the pages which were found were transferred to Nvivo. This search covered the pages published in the 5 years between 01 January 2012 and 08 April 2017. After being transferred to Nvivo, the photos were reviewed, and they were coded according to their content.

\subsection{Creation of Coding Scale}

How to code the photos shared by bloggers was an important problem. To overcome this problem, firstly, the categories published by the Turkish Ministry of Culture and Tourism were is taken as a basis. Secondly, within this list and using studies on the tourism of the countries (Choi et al., 2007; Cakmak \& Isaac, 2012; Gaman \& Răcășan, 2015; Li \& Wang, 2011; Stepchenkova \& Morrison, 2006), the coding scale was created. In the data collection process, the coding scale was continuously developed and according to the similarities of the data, specific codes were created for this study (Table 1).

\subsection{Coders and Reliability}

After the data obtained from the websites were transferred to the Nvivo software, they were coded by three research assistants from the Department of Public Relations and Advertising. For proper content analysis, research assistants who coded the photographs were individually trained. The training was provided on how to encode each photo and to which categories these should have been added. The researchers of the study completed their training by observing how the coders encoded the data and answering their questions. Then, randomly selected (537) photographs corresponding to approximately $10 \%$ of the sample were coded to measure the intercoder reliability. The Cohen Kappa test was used to measure the conformity between the coders in the coding process of the photographs. 
Table 1. Coding Table and Descriptions

\begin{tabular}{ll}
\hline Categories & Explanations \\
\hline Food \& Beverage & $\begin{array}{l}\text { The images related to food and beverages are coded in this category. Places such as photos of } \\
\text { the bloggers while eating, images of places where food or beverages are served, or places where } \\
\text { these products are sold are coded in this category. Accordingly, sub-categories such as teacups, } \\
\text { Turkish coffee, wine, Turkish delight or Café - Restaurant were created. }\end{array}$
\end{tabular}

Life and Culture

The images showing the social situation in Turkey, which transmits images to a region's cultural and business life were evaluated in this category. In this category, although some images are describing how people live and where they are engaged, street life (Tradesmen), animals (cats), social events (Gezi Park protests) and cultural objects (Flag) are also considered.

Historical places

In this category, photos about Turkey's historical places are encoded. In addition to historical sites, historical antique cities were also considered in this context. These works are re-coded as sub-categories by their names. For example, Hagia Sophia, Topkapi Palace or other ancient cities.

Environment and Nature Nature photographs from Turkey were evaluated in this context. Mountains, seas or beaches attraction are covered in this context. Moreover, the natural attractions which are unique to Turkey such as fairy chimneys or Pamukkale travertine are also included as the sub-categories in this context.

City Architecture and Transportation

Activities
This category seems like "Life and Culture"; nevertheless, the categories in this section are more related to the infrastructure, transportation and architecture of a city. The photographs that the bloggers shared, the panoramic image of a city or the transportation structure of the region are evaluated in this category. Likewise, photos of air transportation (THY) are discussed in this scope.

The activities of bloggers in their travels are coded in this category. For example, photos such as balloon travel, baths and nightlife are evaluated in this context.
Kappa values greater than 0.81 are considered to be almost perfect (Landis \& Koch, 1977, p. 165). In this study, the Kappa values were 0.87 . The reason why congruity between the coders was high was that the photographs showed meanings that were not open to interpretation. For example, encoding Galata Tower not "Galata Tower" but to another category had a low probability. This was because it was only possible if the encoders did not know this place. The coders were familiar with Turkey, and when it was necessary, the researchers helped with the coding process.

\section{Results}

After collecting the data, following the steps of the content analysis process (Şimşek and Ylldırım, 2016), the results were interpreted based on themes. In the next pages, the relationships between the themes and the main issues are presented with tables and graphs.

\subsection{Frequencies of Regions}

Table 2 shows which tourism regions' photos were mostly shared by travel bloggers. As in Table 2 , Istanbul was the most frequently visited city in Turkey. Istanbul, with its population, economic size and other parameters, is Turkey's largest city. In addition to these features, it has a rich history. However, beyond these characteristics, it is also a gateway to foreign countries in terms of transportation. Therefore, the first destination for tourists coming to Turkey is usually Istanbul. More than half of the photos shared by bloggers as shown in Table $2(55 \%)$ were related to Istanbul. Table 2 also shows that, while Turkey's most visited regions were coastal regions such as Antalya, Mugla and
Izmir (Culture and Tourism Ministry, 2016) in this study, the second most visited region was seen as Nevsehir (Cappadocia). The photographs of the Cappadocia region that were shared were close to the sum of the coastal regions in number.

Photos of coastal areas had a share of $17 \%$. These results indicated that bloggers preferred unique and authentic tourism regions of Turkey, rather than marine tourism. Bloggers provided data that could support this claim by the percentage of photos they shared. Photographs related to sea tourism (sea, sea swimming, beach) had a share of $2 \%$ in total. In this context, it is possible to say that unique regions such as Cappadocia attract the attention of all bloggers. Another noteworthy unit of data in Table 1 was that bloggers visited Sanliurfa as an important centre for faith tourism, but they did not share any information about the Mevlana (Rumi) tomb in Konya. Yet, in Turkey's promotional films for tourism, usually Mevlana or whirling dervishes are presented ("Turkey: Home Tanitım Kampanyası").

These results related to the regions were in parallel with the shared pages. Alinear increase was observed between the shared photos and numbers of pages. These results indicated that bloggers had different interests than ordinary tourists. They perceived Turkey's most important tourist destinations and the priority order of these differently. One may state they were interested in attractions that mostly only belonged to Turkey such as Cappadocia or Turkish Tea.

\subsection{Featured tourism potentials of cities}

The results related to the photos shared by bloggers also showed the most popular attractions in the cities (Table 3). In the top 5 most visited cities, Istanbul was 
Table 2. Cities with the most shared photos

\begin{tabular}{|c|c|c|c|c|c|}
\hline \multirow{2}{*}{ Rank } & \multirow{2}{*}{ Destination } & \multicolumn{2}{|c|}{ Photos } & \multicolumn{2}{|c|}{ Pages } \\
\hline & & $\mathbf{n}$ & $\%$ & $\mathbf{n}$ & $\%$ \\
\hline 1 & Istanbul & 1062 & 54.7 & 148 & 40.5 \\
\hline 2 & Nevsehir (Cappadocia) & 406 & 20.9 & 78 & 21.4 \\
\hline 3 & Mugla (Marmaris. Fethiye. Bodrum. Datca. Dalaman) & 151 & 7.8 & 27 & 7.4 \\
\hline 4 & Izmir (Sirince. Ceşme. Ephesus) & 94 & 4.8 & 34 & 9.3 \\
\hline 5 & Antalya (Kas. Alanya) & 72 & 3.7 & 19 & 5.2 \\
\hline 6 & Denizli (Pamukkale) & 57 & 2.9 & 18 & 4.9 \\
\hline 7 & Ankara & 15 & 0.8 & 5 & 1.4 \\
\hline 8 & Adiyaman & 12 & 0.6 & 3 & 0.8 \\
\hline 9 & Sanliurfa & 10 & 0.5 & 4 & 1.1 \\
\hline 10 & Rize & 10 & 0.5 & 4 & 1.1 \\
\hline 11 & Kars & 8 & 0.4 & 3 & 0.8 \\
\hline 12 & Van & 8 & 0.4 & 2 & 0.5 \\
\hline 13 & Canakkale & 7 & 0.4 & 4 & 1.1 \\
\hline 14 & Gaziantep & 6 & 0.3 & 3 & 0.8 \\
\hline 15 & Edirne & 6 & 0.3 & 1 & 0.3 \\
\hline 16 & Diyarbakır & 5 & 0.3 & 2 & 0.5 \\
\hline 17 & Bursa+Uludag & 3 & 0.2 & 2 & 0.5 \\
\hline 18 & Kirklareli & 3 & 0.2 & 1 & 0.3 \\
\hline 19 & Aydin + Kusadasi & 2 & 0.1 & 2 & 0.5 \\
\hline 20 & Others (Aksaray+Erzurum+Mardin+Mersin) & 5 & 0.3 & 5 & 1.4 \\
\hline
\end{tabular}

especially prominent with its historical monuments. The Blue Mosque (111) and Hagia Sophia (88) were the first ones. After the historical monuments, most of the photos in Istanbul were shared about hotels and accommodation. These results indicated that Istanbul was the most prominent city in Turkey in terms of accommodation. Similarly, Antalya was also mostly photographed about its accommodationrelated (12) features. Although there are many historical and natural beauties in this region, bloggers published photographs of mostly hotels and accommodation-related issues.

Perhaps the most prominent image of the Cappadocia region seems to be balloon travel. All bloggers visiting this area shared images of balloon travel (107) as well as photos of the Fairy Chimneys (95). Mugla and Izmır were generally popular with their rural areas or their districts rather than centres.

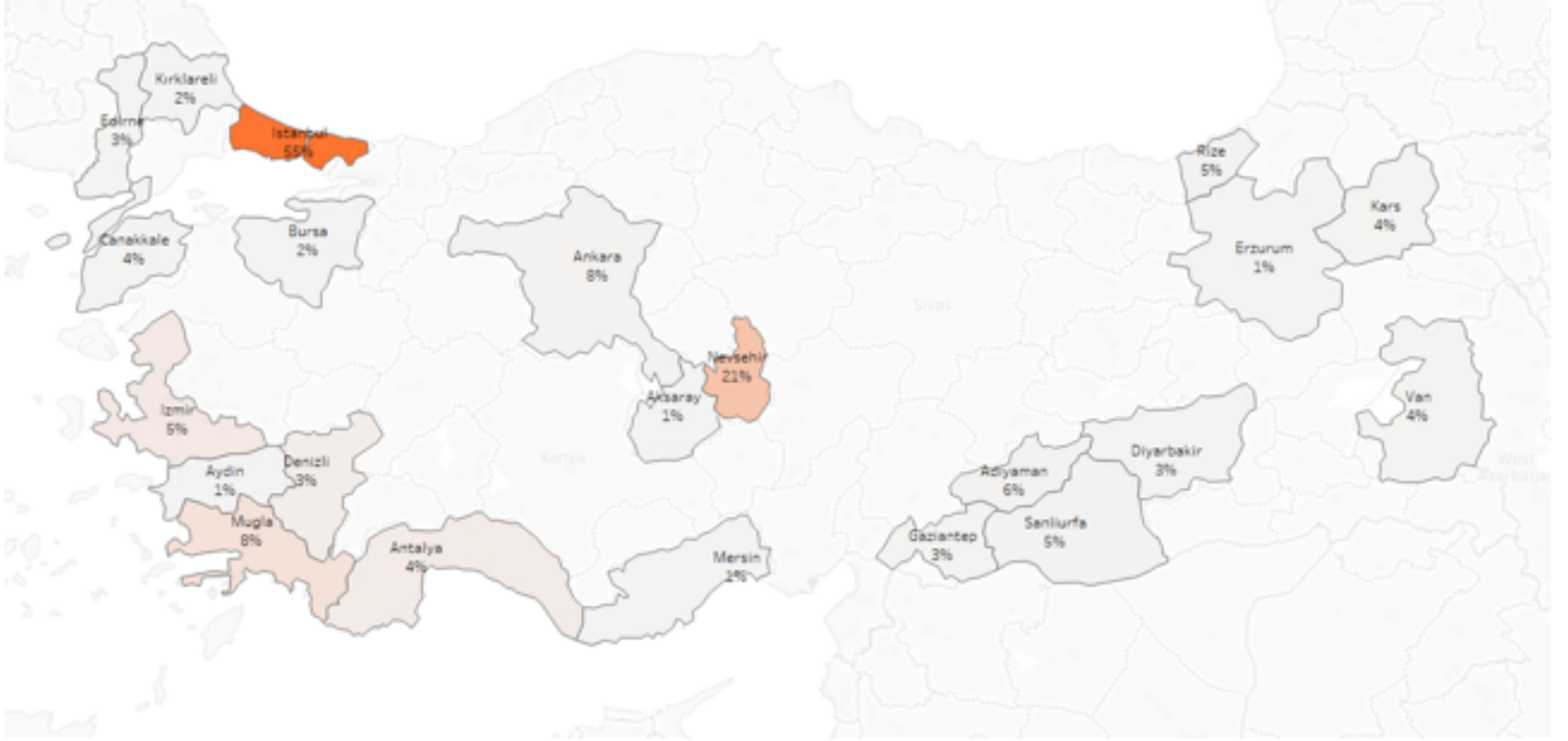

Figure 2. Most shared photos by cities 
No photographs of the centre of Mugla were even included in the findings. In Izmir, the most ancient city of Ephesus (59) came to the fore. Another point of interest was the Sirince village, which has been mentioned in recent years (21). In Mugla, the most commonly mentioned destinations were Fethiye (90) and Bodrum (48). These were followed by sea activities (27). In this context, it is possible to state that this region was more prominent with sea tourism. On the other hand, a situation similar to the interest in balloon travel in Cappadocia was also valid for this region. Parachute jumping in Fethiye (23) stood out as the most prominent tourist activity.

Apart from these data, the most common photos were about food and beverages. Especially in Istanbul, cafes, restaurants and food were frequently shared. The results reveal that bloggers were interested in Istanbul especially in terms of gastronomy tourism. Another feature that made Istanbul interesting was street cats' photos that bloggers shared. Cats' (31) photos had a close rate of interest to the Topkapı Palace (34). It is also possible to consider not only bloggers but also many other people to be interested in Istanbul's cats, considering there is a documentary about them (Torun, 2016). Many bloggers who visited Istanbul shared cats as well as street photographs. Some authors even shared separate pages about Istanbul cats (www.bkpk.me www.pointsandtravel.com).

\subsection{Featured tourism potentials of cities}

In the study, the nationalities of bloggers were organized according to the countries they indicated in their Twitter addresses. But some authors defined their country as the World instead of writing countries, while others left their countries blank. Especially those who stated themselves as travellers did not prefer to belong to a particular country. The countries of the first 120 bloggers in the Rise Travel list are listed in Table 4. The list mostly included English-speaking countries. Among these, the United States came first, followed by the United Kingdom and Canada. However, more than half of American bloggers shared-nothing related to Turkey. Therefore, British bloggers posting pages and sharing photos about Turkey were more frequently

Table 3. Topics of shared photos of the top 5 most visited regions/cities

\begin{tabular}{|c|c|c|c|c|c|}
\hline & Istanbul & Antalya & Izmir & $\begin{array}{l}\text { Cappadocia } \\
\text { (Nevsehir) }\end{array}$ & Mugla \\
\hline & (n: 1062) & (n: 72) & $(\mathrm{n}: 94)$ & (n: 406) & $(\mathrm{n}: 151)^{\star}$ \\
\hline Hagia Sophia & 88 & & & & \\
\hline Balloon Tours & & & & 107 & \\
\hline Bodrum & & & & & 48 \\
\hline Cafe - Restaurant & 40 & & 2 & & 6 \\
\hline Cityscape & 66 & 8 & 4 & 26 & 20 \\
\hline Mountain or valleys & & & & & 14 \\
\hline Coast, Beach or Dock & & 10 & & & 27 \\
\hline Ephesus & & & 59 & & \\
\hline Fethiye & & & & & 90 \\
\hline Gezi Park protests & 47 & & & & \\
\hline Graffiti & 43 & & & & \\
\hline Grand Bazaar & 49 & & & & \\
\hline Portrait of People & 50 & 4 & 3 & 34 & 9 \\
\hline Cats & 31 & & & & \\
\hline Architectural and decorative works & 34 & & & & \\
\hline Hotels' rooms & 41 & 11 & 8 & 13 & 7 \\
\hline Hotels - Resort & 32 & 3 & 5 & 12 & \\
\hline Parachuting & & & & & 23 \\
\hline Fairy Chimneys & & & & 95 & \\
\hline Sirince & & & 21 & & \\
\hline Street (General) & 29 & & 2 & 3 & \\
\hline People or crowd photos in streets & 63 & & 6 & & \\
\hline Blue Mosque & 111 & & & & \\
\hline Topkapi Palace & 38 & & & & \\
\hline Food \& Beverage (General) & 76 & & 5 & 7 & \\
\hline
\end{tabular}


Table 4. Distribution of photos shared by nationality

\begin{tabular}{|c|c|c|}
\hline Country & $\begin{array}{l}\text { Blogger shared pho- } \\
\text { tos of Turkey (n) }\end{array}$ & Top 5 photos shared by bloggers \\
\hline USA & $46 / 60$ & $\begin{array}{l}\text { Istanbul (205), Cappadocia (69), Hagia Sophia (29), Fairy Chimneys (29), Food } \\
\& \text { Beverage (28) }\end{array}$ \\
\hline Great Britain & $14 / 19$ & $\begin{array}{l}\text { Istanbul (361), Cappadocia (76), Food \& Beverage (73), Hotels' rooms (69), } \\
\text { Fethiye (65) }\end{array}$ \\
\hline Canada & $13 / 16$ & $\begin{array}{l}\text { Cappadocia (68), Istanbul (63), Portrait of People (34), Balloon Tours (34), Pa- } \\
\text { mukkale (30) }\end{array}$ \\
\hline World & $12 / 17$ & $\begin{array}{l}\text { Istanbul (168), Gezi Park protests (49), Cappadocia (37), Graffiti (28), People or } \\
\text { crowd photos in streets (27) }\end{array}$ \\
\hline Australia & $9 / 10$ & Istanbul (72), Cappadocia (37), Bodrum (20), Fairy Chimneys (19) \\
\hline Unspecified & 7 & $\begin{array}{l}\text { Istanbul (106), Cityscape (16), Blue Mosque (13), Other Mosques (10), Food \& } \\
\text { Beverage (10) }\end{array}$ \\
\hline India & $5 / 8$ & $\begin{array}{l}\text { Istanbul (31), Cats (14), Dolmabahce Palace (9), Topkapi Palace (6), Cappadocia } \\
\text { (3) }\end{array}$ \\
\hline Italy & $3 / 5$ & $\begin{array}{l}\text { Cappadocia (10), Fairy Chimneys (7), Other Churches (7), Life of Village (1), } \\
\text { Underground City (1) }\end{array}$ \\
\hline Others & $15 / 23$ & $\begin{array}{l}\text { Cappadocia (73), Portrait of People (61), Istanbul (56), Other Ancient Cities (31), } \\
\text { Coast, Beach or Dock (17) }\end{array}$ \\
\hline
\end{tabular}

observed than those from the United States.

According to their nationality, many bloggers' tourism-interest for Turkey was Istanbul. On the other hand, some bloggers of different nationalities had more interest in Cappadocia than Istanbul. Except for regions the US and the UK, bloggers also shared many photos about the food culture in Turkey. The preferences of bloggers, who could not be identified with a country and who claimed to be a citizen of the world differed in comparison to others. In this category, it seems that Istanbul and Cappadocia, as well as Gezi protests, graffiti and people attracted more interest. It could be stated that bloggers who described themselves as permanent travellers were interested mostly in life in Turkey. Additionally, the preferences of bloggers from India were different from those of others. Their interest was more directed towards old palaces, as well as cats.

\subsection{Featured tourism potentials of cities}

The results obtained from the datawere categorized into eight categories. These results demonstrated how bloggers perceived Turkey as a tourism destination. In a sense, it reflects the characteristics of Turkey2s image perceived by bloggers. The results indicated that bloggers are often interested in the activities that can be experienced only in Turkey but not in another country (Table 5). Natural and historical places were the first ones among these. For example, after Istanbul, the Cappadocia region's activities were among the second most frequently shared photos about Turkey. Bloggers shared many photos of both the history and nature of Cappadocia. In these photos, it was determined that bloggers were particularly interested in balloon tours and fairy chimneys. Likewise, the Pamukkale region and the travertines located here were one of the most frequently visited areas for bloggers.
Apart from these, the mountains and beaches in the Mediterranean region were also the attractions in which bloggers were interested.

After nature and environment attractions, bloggers mostly shared photos of Turkey's cultural and social life. Portrait photographs with specific people took first place. Similarly, people who were seen randomly or in general street views were the second most shared photos in this category. Furthermore, not only people outside but animals like street cats were also frequently shared on pages. While cats were never shared in other cities, in a sense, they were an icon that defines Istanbul after the historical monuments of the city. All cat photographs that were shared belonged to this city (Table 3 ). Bloggers also shared photos of shopping activities frequently. The Grand Bazaar and the Spice Bazaar, which are both historical places and shopping places, were among the photos taken by bloggers. The results showed that bloggers also shared modern store photos. In this sense, we may say bloggers considered Turkey not only a travel destination but also an attraction of shopping.

Another category that is frequently seen among the photos shared by bloggers was the food culture. Among these photos, the most frequently shared food photos were cafe and restaurant images. It might be inferred from the shared photos that experiencing food and beverages in Turkey was popular among bloggers. In addition to the food photos in general, the names of some foods and beverages were mentioned, and their photographs were shared. Among them, Turkish tea took first place. Turkish tea in all of the visuals in the photos was shown in Turkish tradition tea glasses or samovars. In addition to these food and beverage photos, wines which are produced in Turkey ranked the second most frequently shared photos. Furthermore, Turkish coffee photos were also frequently shared. 


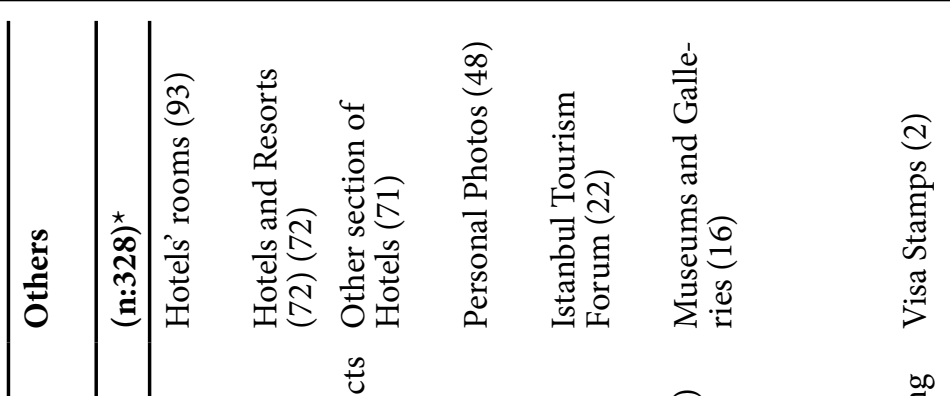

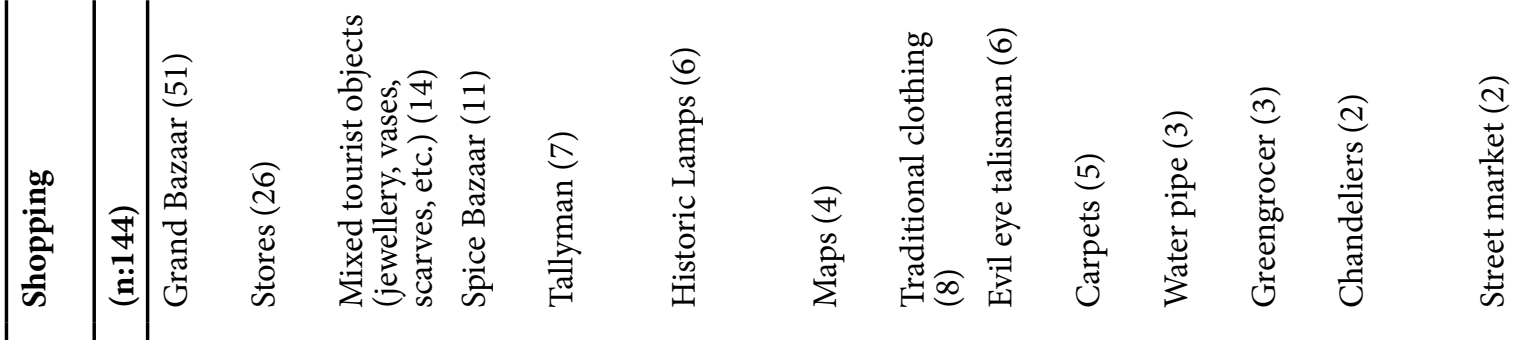

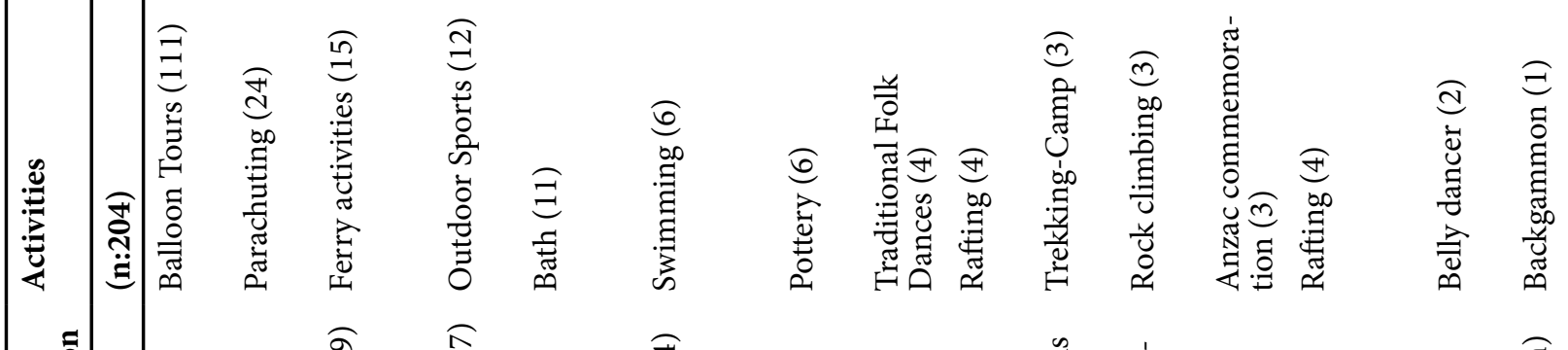

望|

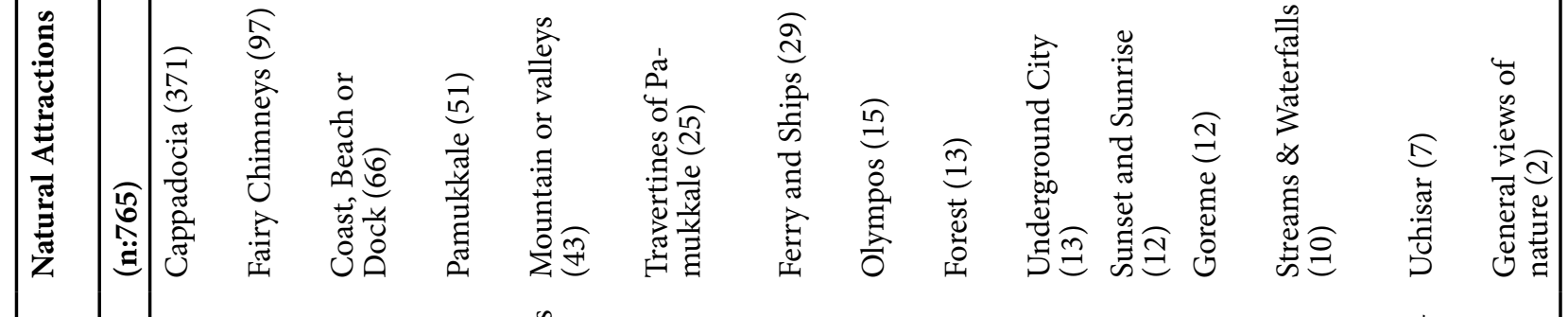

|

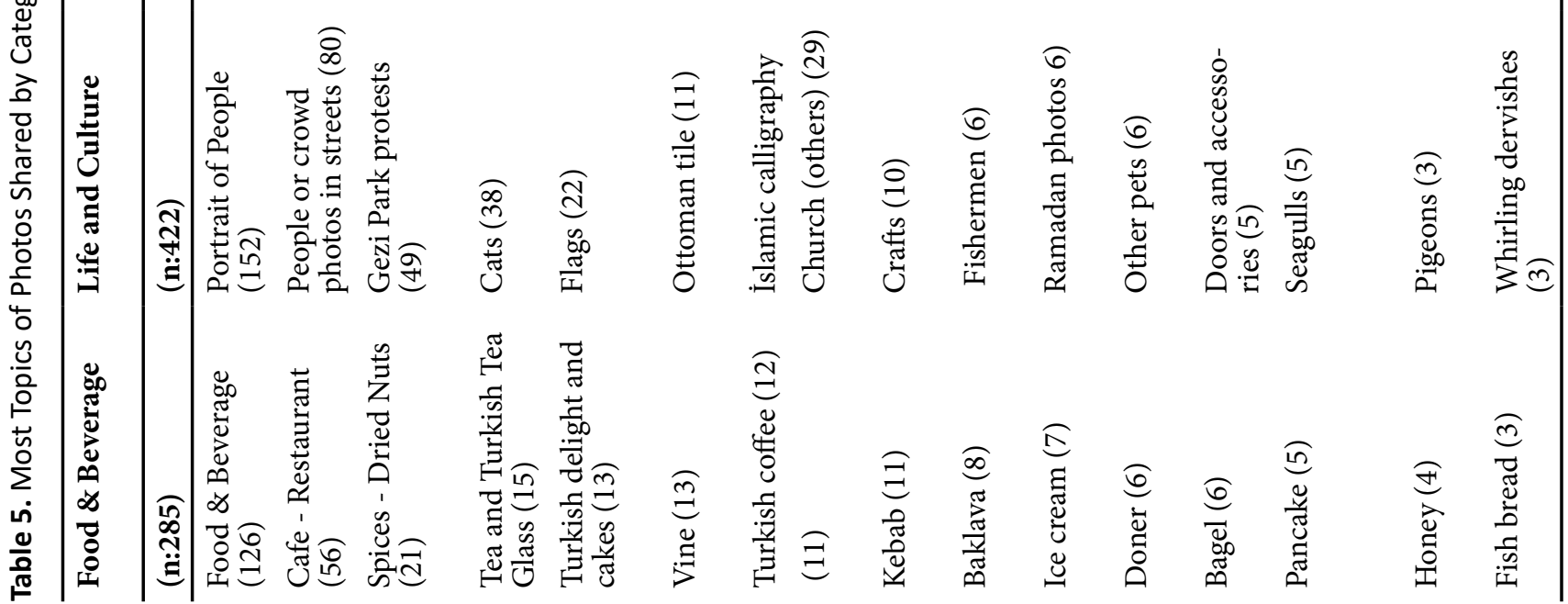


Turkey has a rich historical past. For this reason, the included photographs were often found in the blogs in a variety of ways. Historical mosques were one of the most frequently shared historical sites. Especially the mosques and churches in Istanbul are among the most photographic places. After the mosques, most of the places of interest are ancient settlements. The first place was the Ephesus ancient city. Although a small number of photos were shared outside of Ephesus, many different regions of Turkey were shared by bloggers. Most of the historical artefacts shared outside the ancient cities are the places in Istanbul. Only Nemrut is outside Istanbul. Yet, the photos shared here were very few, and the ratio in the total historical works was $1 \%$. On the other hand, there are many historical places in Cappadocia, and many photographs of bloggers were identified. However, a few of these photos were related to historical sites. This region has become more prominent with its natural beauties such as fairy chimneys and balloon travel.

The first results obtained from the data revealed that bloggers presented a lot of information reflecting the urban architecture and transportation of the regions they visited. So, we took this as a separate category in this context. In this category, photos that reflected a panoramic view of a city or region were shared most commonly. There were such images in the first five most visited cities (Table 3). Additionally, street photographs and architectural details of the city were also shared in the photographs, reflecting the structure and life of a city. Apart from these, wall paintings and graffiti on the streets were taken on bloggers websites only in Istanbul. As Istanbul's cats, some authors and graffiti on walls were also shared. At the first place in terms of transportation were photos related to Turkish Airlines (THY). The photographs which were shared usually belonged to the THY lounge at the airports for passengers rather than THY's aeroplanes. Transportation was shared also at the same time to reflect the structure of Turkey, whereas so many transportation photos were about bus travel. Similarly, shared taxi (dolmush) rides were shared more frequently than taxi travel.

Apart from the categories above, the topics with very few sub-categories but the topics of interest of bloggers were derived from the data. Among these, places, where writers stayed, were the first places. The authors introduced photographs in hotels and holiday resorts, while also providing hints about the quality of accommodation companies. For this reason, historical places and natural beauties as well as rooms, activity venues, were shared from many places of hotels. On the other hand, we had the chance to determine what kind of tourism activities bloggers were interested in the shared photographs. Accordingly, the most popular activities of bloggers were nature sports. These included parachuting and sea sports. Apart from these, although there are many museums in Turkey, bloggers were found to be interested in such places by very little. 16 photographs of all museums visited by bloggers were determined. These photos belonged to only 4 museums.

\section{Conclusion and Discussion}

In this study, we aimed to present travel bloggers' perceptions of Turkey. Rather than how Turkey self-perceives its identity, we tried to describe how someone from "outside" of Turkey considered it, which features were observed at the top, and in terms of tourism potential, we investigated in what travel bloggers were interested in Turkey over photographs they took.

The results showed that the most frequently visited city was Istanbul and also historical places such as the Blue Mosque, Hagia Sophia. These results were predictable. In contrast, we achieved some unexpected new findings that could offer clues about the tourism potential of Turkey. For example, bloggers were more interested in Turkey's history and natural attractions, as well as places bearing traces of daily life rather than sea tourism. This means that bloggers were constantly travelling beyond ordinary tourists, and therefore, they did not choose a package of services offered by tourism agencies, but they created their travel route to learn about a country or destination. On the other hand, this situation was also perceived as revealing the unseen richness of Turkey. Because bloggers are a popular audience, it may also be stated that bloggers' preferences encouraged readers to be interested in these areas (Song et al., 2007). In this context, we believe it would be useful to consider this information for Turkey's tourism marketing efforts to reach targeted potential consumers and transmit the correct message. The findings obtained in this study might be guiding for reaching targeted potential customers and efforts for the right marketing communication campaign in Turkey's tourism marketing.

Tourist who visited it perceived Turkey about its historical artefacts, ancient ruins and "historical" concepts. At the same time, visitors identified Turkey with adjectives as exciting, exotic and colourful (Baloglu, 2001). In this study, abundant data were obtained to support these findings. Blogger shared many photos of Turkey's social life and gastronomy (See. Table 5). The findings of the study allowed some specific issues to emerge. In this context, it was possible to access some information on which issue of Turkey's promotion should be brought to the fore or used in marketing campaigns. When we examined the past and present campaigns, we saw that some basic themes such as sea, tulip, and whirling dervish or Istanbul mosques were brought to the forefront. However, this study revealed that most bloggers in tourism were not interested in many of these themes. For example, photographs from Cappadocia were more in numbers than those from all the Mediterranean and Aegean coasts of Turkey. Similarly, street cats of Istanbul attracted attention 
as much as the Topkapi Palace. On the other hand, some of the features highlighted in these campaigns were never seen (Mevlana tomb, whirling dervishes, etc.). These results suggested that there may be evidence that these messages do not correctly reach the relevant targets in existing communication campaigns or the target audience for Turkey is not analyzed correctly. Therefore, it may be concluded that a proper message strategy has not been created.

One of the results of this study is the big gap between the identity of Tukey's which is seen by Turkey itself and seen by outsiders. According to the results of the research, bloggers are more interested in Turkey's unique features and exotic aspects. It is understood from this case, bloggers only find these values in Turkey. Tourism destinations with high added value in Turkey for tourists; are its social, cultural and historical values rather than the sea or the hotel tourism in many countries. Yet, when we look at the regional result of Turkey's visitors, sea tourism is still higher in all areas (Republic of Turkey Ministery of Culture and Tourism, 2020). It is understood from this case, Turkey's important places which are more important for bloggers are still not promoted enough.

On the other hand, as has been shown in previous studies, tourists' view of destinations differs from the general image of countries. For instance, although the perception of tourists towards a country is negative, they can view some attractions in that country positively. (Campo \& Alvarez, 2014; Martínez \& Alvarez, 2010; Nadeau et al., 2008; Stepchenkova \& Morrison, 2006). As the results of this study point out, the characteristics of tourist attractions are more interesting for bloggers than the general image of a country. Some of earlier studies have shown that Turkey's negative image of the overall brand. (Anholt, 2010, p. 108). However, when we look at the results of research in terms of Turkey's tourism image, the number of states reporting the favourable opinion of Turkey is higher than the negative opinion. (Baloglu, 2001; Campo \& Alvarez, 2014). The results in this regard support previous research. Yet, Approaches that the image of the country has a halo effect (Han, 1989) on the image of the destination were not observed in this study.

\section{References}

Akehurst, G. (2008). User-generated content: The use of blogs for tourism organisations and tourism consumers. Service Business, 3(1), 51. https://doi.org/10.1007/ s11628-008-0054-2

Albers, P. C., \& James, W. R. (1988). Travel photography: A methodological approach. Annals of Tourism Research, 15(1), 134-158.

Anholt, S. (2010). Places: identity, image and reputation. Basingstoke: Palgrave Macmillan.

Baldauf, A., Cravens, K. S., Diamantopoulos, A., \& ZeugnerRoth, K. P. (2009). The Impact of Product-Country Image and Marketing Efforts on Retailer-Perceived Brand
Equity: An Empirical Analysis. Journal of Retailing, 85(4), 437-452. https://doi.org/10.1016/j.jretai.2009.04.004

Baloglu, S. (2001). Image variations of Turkey by familiarity index: informational and experiential dimensions. Tourism Management, 22(2), 127-133.

Baloglu, S., \& Mangaloglu, M. (2001). Tourism destination images of Turkey, Egypt, Greece, and Italy as perceived by US-based tour operators and travel agents. Tourism Management, 22(1), 1-9. https://doi.org/10.1016/ S0261-5177(00)00030-3

Baloglu, S., \& McCleary, K. W. (2016). U.S. International Pleasure Travelers' Images of Four Mediterranean Destinations: A Comparison of Visitors and Nonvisitors. Journal of Travel Research, 38(2), 144-152. https://doi. org/10.1177/004728759903800207

Barich, H., \& Kotler, P. (1991). A framework for marketing image management. MIT Sloan Management Review, 32(2), 94.

Campo, S., \& Alvarez, M. D. (2014). Can tourism promotions influence a country's negative image? An experimental study on Israel's image. Current Issues in Tourism, 17(3), 201-219. https://doi.org/10.1080/13683500.2013.766 156

Choi, S., Lehto, X. Y., \& Morrison, A. M. (2007). Destination image representation on the web: Content analysis of Macau travel-related websites. Tourism Management, 28(1), 118-129. https://doi.org/10.1016/j. tourman.2006.03.002

Connell, J. (2005). Toddlers, tourism and Tobermory: Destination marketing issues and television-induced tourism. Tourism Management, 26(5), 763-776.

Cosenza, T. R., Solomon, M. R., \& Kwon, W.-s. (2015). Credibility in the blogosphere: A study of measurement and influence of wine blogs as an information source. Journal of Consumer Behaviour, 14(2), 71-91. https:// doi.org/10.1002/cb.1496

Cox, C., Burgess, S., Sellitto, C., \& Buultjens, J. (2009). The Role of User-Generated Content in Tourists' Travel Planning Behavior. Journal of Hospitality Marketing \& Management, 18(8), 743-764. https://doi. org/10.1080/19368620903235753

Currie, R. R., Wesley, F., \& Sutherland, P. (2008). Going where the Joneses go: Understanding how others influence travel decision-making. International Journal of Culture, Tourism and Hospitality Research, 2(1), 12-24. https:// doi.org/10.1108/17506180810856112

Çakmak, E., \& Isaac, R. K. (2012). What destination marketers can learn from their visitors' blogs: An image analysis of Bethlehem, Palestine. Journal of Destination Marketing \& Management, 1(1-2), 124-133. https:// doi.org/10.1016/j.jdmm.2012.09.004

Echtner, C. M., \& Ritchie, J. B.R. (1993). The Measurement of Destination Image: An Empirical Assessment. Journal of Travel Research, 31(4), 3-13. https://doi. org/10.1177/004728759303100402

Gaman, G., \& Răcășan, B. S. (2015). Tourist Image Of Romania Reviewed By International Travel Guides. Comparative Study: English, French And German Editions. Revista de tourism-studii si cercetari in turism, (19), 60-73.

Garrod, B. (2008). Understanding the Relationship between Tourism Destination Imagery and Tourist Photography. 
Journal of Travel Research, 47(3), 346-358. https://doi. org/10.1177/0047287508322785

Han, C. M. (1989). Country image: halo or summary construct? Journal of marketing research, 26(2), 222.

Hsieh, M.-H., Pan, S.-L., \& Setiono, R. (2004). Product-, Corporate-, and Country-Image Dimensions and Purchase Behavior: A Multicountry Analysis. Journal of the Academy of Marketing Science, 32(3), 251-270. https://doi.org/10.1177/0092070304264262

Joyner, J. (2008). Bloggers as Opinion Leaders. Retrieved from http://www.outsidethebeltway.com/bloggers_ as_opinion_leaders/

Kim, H., \& Richardson, S. L. (2003). Motion picture impacts on destination images. Annals of Tourism Research, 30(1), 216-237. https://doi.org/10.1016/S01607383(02)00062-2

Landis, J. R., \& Koch, G. G. (1977). The Measurement of Observer Agreement for Categorical Data. Biometrics, 33(1), 159. https://doi.org/10.2307/2529310

Lee, R., \& Lockshin, L. (2012). Reverse country-of-origin effects of product perceptions on destination image. Journal of Travel Research, 51(4), 502-511.

Li, D., Lu Wang, C., Jiang, Y., R. Barnes, B., \& Zhang, H. (2014). The asymmetric influence of cognitive and affective country image on rational and experiential purchases. European Journal of Marketing, 48(11/12), 2153-2175. https://doi.org/10.1108/EJM-09-2012-0505

Li, X., \& Wang, Y. (2011). China in the eyes of western travellers as represented in travel blogs. Journal of Travel \& Tourism Marketing, 28(7), 689-719.

Light, D. (2007). Dracula tourism in Romania Cultural identity and the state. Annals of Tourism Research, 34(3), 746765. https://doi.org/10.1016/j.annals.2007.03.004

Ma, Y., Xiang, Z., Du, Q., \& Fan, W. (2018). Effects of userprovided photos on hotel review helpfulness: An analytical approach with deep leaning. International Journal of Hospitality Management, 71, 120-131. https://doi.org/10.1016/j.ijhm.2017.12.008

MacKay, K. J., \& Fesenmaier, D. R. (1997). Pictorial element of destination in image formation. Annals of Tourism Research, 24(3), 537-565. https://doi.org/10.1016/ S0160-7383(97)00011-X

Markwell, K. W. (1997). Dimensions of photography in a nature-based tour. Annals of Tourism Research, 24(1), 131-155. https://doi.org/10.1016/S01607383(96)00053-9

Markwick, M. (2001). Postcards from Malta. Annals of Tourism Research, 28(2), 417-438. https://doi. org/10.1016/S0160-7383(00)00049-9

Martínez, S. C., \& Alvarez, M. D. (2010). Country Versus Destination Image in a Developing Country. Journal of Travel \& Tourism Marketing, 27(7), 748-764. https:// doi.org/10.1080/10548408.2010.519680

Mossberg, L., \& Kleppe, I. A. (2005). Country and destination image - different or similar image concepts? The Service Industries Journal, 25(4), 493-503. https://doi. org/10.1080/02642060500092147

Munar, A. M., \& Jacobsen, J. K. S. (2014). Motivations for sharing tourism experiences through social media. Tourism Management, 43, 46-54. https://doi. org/10.1016/j.tourman.2014.01.012
Nadeau, J., Heslop, L., O’Reilly, N., \& Luk, P. (2008). Destination in a country image context. Annals of Tourism Research, 35(1), 84-106.

Pharr, J. M. (2015). Synthesizing Country-of-Origin Research from the Last Decade: Is the Concept Still Salient in an Era of Global Brands? Journal of Marketing Theory and Practice, 13(4), 34-45. https://doi.org/10.1080/106966 79.2005.11658557

Phau, I., Shanka, T., \& Dhayan, N. (2010). Destination image and choice intention of university student travellers to Mauritius. International Journal of Contemporary Hospitality Management, 22(5), 758-764. https://doi. org/10.1108/09596111011053846

Ren, M., Vu, H. Q., Li, G., \& Law, R. (2020). Large-scale comparative analyses of hotel photo content posted by managers and customers to review platforms based on deep learning: Implications for hospitality marketers. Journal of Hospitality Marketing \& Management, 1-24. https://doi.org/10.1080/19368623.2020.1765226

Republic of Turkey Ministery of Culture and Tourism (2020, December 30). Tourism Statistics of Turkey. Retrieved from https://yigm.ktb.gov.tr/TR-9851/turizmistatistikleri.html

Song, X., Chi, Y., Hino, K., \& Tseng, B. (2007). Identifying opinion leaders in the blogosphere. In M. J. Silva, A. O. Falcão, A. A. F. Laender, R. Baeza-Yates, D. L. McGuinness, B. Olstad, \& $\varnothing$. H. Olsen (Eds.), Proceedings of the sixteenth ACM conference on Conference on information and knowledge management - CIKM ‘07 (p. 971). New York, New York, USA: ACM Press. https://doi. org/10.1145/1321440.1321588

Stepchenkova, S., \& Mills, J. E. (2010). Destination Image: A Meta-Analysis of 2000-2007 Research. Journal of Hospitality Marketing \& Management, 19(6), 575-609. https://doi.org/10.1080/19368623.2010.493071

Stepchenkova, S., \& Morrison, A. M. (2006). The destination image of Russia: From the online induced perspective. Tourism Management, 27(5), 943-956. https://doi. org/10.1016/j.tourman.2005.10.021

Stepchenkova, S., \& Zhan, F. (2013). Visual destination images of Peru: Comparative content analysis of DMO and user-generated photography. Tourism Management, 36, 590-601. https://doi.org/10.1016/j. tourman.2012.08.006

Şimşek, H., \& Yıldırım, A. (2016). Sosyal Bilimlerde Nitel Araştırma Yöntemleri (10th ed.). Ankara: Seçkin Yayıncılık.

Torun, C. (Director) (2016). Kedi. [Film], Termite Films.

Tudor, R. (2012). The image of tourist destinations represented in travel blog photography. Case study: Romania's image reflected in French bloggers photos. Revista de turism-studii si cercetari in turism. (13).

Turkey:Home Tanıtım Kampanyası. Retrieved from https:// www.youtube.com/watch?v=pvTRgukcw_8

Yüksel, A., \& Akgül, O. (2007). Postcards as affective imagemakers: An idle agent in destination marketing. Tourism Management, 28(3), 714-725. https://doi. org/10.1016/j.tourman.2006.04.026

Zehrer, A., Crotts, J. C., \& Magnini, V. P. (2011). The perceived usefulness of blog postings: An extension of the expectancy-disconfirmation paradigm. 
Tourism Management, 32(1), 106-113. https://doi. org/10.1016/j.tourman.2010.06.013

Zhang, H., Xu, F., Leung, H. H., \& Cai, L. A. (2015). The Influence of Destination-Country Image on Prospective Tourists' Visit Intention: Testing Three Competing Models. Asia Pacific Journal of Tourism Research, 21(7), 811-835. https://doi.org/10.1080/10941665.2015.1075566

Zhang, K., Chen, Y., \& Li, C. (2019). Discovering the tourists' behaviours and perceptions in a tourism destination by analyzing photos' visual content with a computer deep learning model: The case of Beijing. Tourism Management, 75, 595-608. https://doi.org/10.1016/j. tourman.2019.07.002

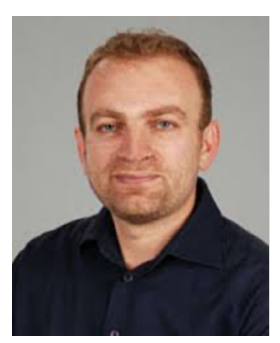

Adil Bical graduated from Akdeniz University, Department of Public Relations and Advertising. He also holds a PhD and M.Sc. in Public Relations and Advertising from the University of Anadolu. $\mathrm{He}$ is currently a research assistant at the Communication Faculty of Gaziantep University. His research interests include customer engagement, digital advertising

and gamification.

ORCID: 0000-0001-6139-5497

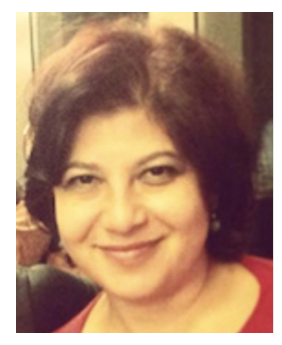

Mesude Canan Ozturk is currently a Professor in Communication Science Faculty, Department of Public Relations and Advertising at Anadolu University. She received her $\mathrm{PhD}$ degree from Ankara University, Graduate School of Social Sciences, Public Relations and Publicity. She lectures Social Campaigns, Public Relations Campaigns, Digital Public Relations, International Advertising and PR. She also studies on Corporate Communication, Digital Communication \&New Media, Corporate Social Responsibilities, Social Innovation.

ORCID: 0000-0002-2677-6902 